International Journal of Zoological Investigations

Contents available at Journals Home Page: www.ijzi.net

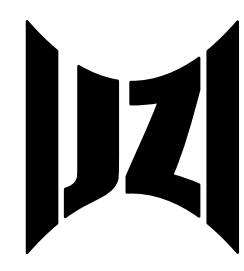

ISSN: 2454-3055

\title{
Acute Toxicity of Mercuric Chloride to the Freshwater Catfish, Heteropneustes fossilis
}

\author{
Srivastav Ajai K. ${ }^{*}$, Agarwal Khushbu${ }^{1}$, Kumar Abhishek ${ }^{1}$, Prasad ManiRam ${ }^{1}$ and Suzuki N. ${ }^{2}$ \\ 1Department of Zoology, DDU Gorakhpur University, Gorakhpur 273009, India \\ ${ }^{2}$ Noto Marine Laboratory, Institute of Nature and Environmental Technology, Division of Marine Environmental Studies, Kanazawa \\ University, Noto-cho, Ishikawa 927-0553, Japan
}

${ }^{*}$ Corresponding Author

Received: $10^{\text {th }}$ June, 2020

Accepted: $11^{\text {th }}$ July, 2020

Published online: $12^{\text {th }}$ July, 2020

https://doi.org/10.33745/ijzi.2020.v06i02.008

\begin{abstract}
The present study was designed to investigate the toxic effect of mercuric chloride on a freshwater catfish Heteropneustes fossilis, in terms of fish mortality test. After exposure to various concentrations of mercuric chloride, the $\mathrm{LC}_{50}$ values of mercuric chloride for $H$. fossilis at $24,48,72$ and $96 \mathrm{~h}$ are $0.96,0.91,0.81$ and $0.70 \mathrm{mg} / \mathrm{L}$, respectively. Toxicity of mercuric chloride to $H$. fossilis has been compared with other fish species and it is concluded that $H$. fossilis is hardy fish.
\end{abstract}

Keywords: Heavy metal, Mercuric chloride, $\mathrm{LC}_{50}$, Heteropneustes fossilis

Citation: Srivastav Ajai K., Agarwal Khushbu, Kumar Abhishek, Prasad ManiRam and Suzuki N.: Acute toxicity of mercuric chloride to the freshwater catfish, Hetropneustes fossilis. Intern. J. Zool. Invest. 6 (2): 301-305, 2020. https://doi.org/10.33745/ijzi.2020.v06i02.008

\section{Introduction}

Pesticides have been used by the human beings for control of insect vectors of diseases and increased yields of many crops. Use of these pesticides causes problems to organisms including human beings. Pesticides may have dual actions - they are important in controlling injurious pests but they may also present a hazard to species not considered to be pests in the environment. The hazard becomes more serious when pesticides directly affect populations of economically important non-target organisms or poison organisms which are eaten by economically important animals and human beings.

Fishes, both freshwater and marine, are the most important non-target inhabitants of the aquatic ecosystem which are affected by toxicants. Fish are economically very 
important and influence the human beings in various ways. Their food value is now well known as it provides the much needed protein, vitamin $A$ and $D$, and other elements.

Mercury $(\mathrm{Hg})$ is particularly of great concern due to its high toxicity (Guedenon et al., 2012). Naturally it is present as a mineral and is distributed throughout the environment as a result of natural or human activities. Natural mercury occurs due to the degassing of the earth's crust through volcanos, and also by evaporation from the oceans (Boening, 2000). The other source of mercury is by burning of fossil fuels. The largest consumers of mercury, amounting to $55 \%$ of total consumption, are chloralkali, electrical equipments, paint and wood pulping industries. Mercury is also being used in agriculture principally as fungicides, batteries, medicine and dentistry. However, due to strict regulations the use of mercury has been reduced in recent years. Inorganic mercury can be microbiologically converted into methyl-mercury (Joshi et al., 2011, 2012, 2013; Guedenon et al., 2012). Mercury exposure to fish produced haematological, histopathological and reproductive effects (Shah and Altindag, 2004; Arabi, 2004; Sarmento et al., 2004; Drevnick and Sandheinrich, 2003; Crump and Trudeau, 2009; Gupta, 2014).

The present study was designed to investigate the toxic effect of heavy metalmercuric chloride on a freshwater catfish Heteropneustes fossilis, in terms of fish mortality test.

\section{Materials and Methods}

\section{Collection and handling of the fish:}

Stinging catfish, Heteropneustes fossilis were used as test fish in this study because this species is hardy, readily available, easy to handle, can be held in captivity for long period, and form an important species in many water resources.

Adult $H$. fossilis (both sexes, body weight 29-36 g) were collected locally and inspected for external signs of injury and diseases. Those, which showed such symptoms, were discarded and only the healthy ones were selected for experiments. These fish were acclimatized to the laboratory conditions (under natural photoperiod and temperature $28.4 \pm 1.2 \mathrm{C}$ ) for two weeks in plastic pools containing $500 \mathrm{~L}$ of dechlorinated tap water. During acclimatization the fish were fed daily with wheat flour pellets and ground dried shrimps, 2-3 times per day. Water was renewed daily after cleaning the fecal matter and leftover food. All care was taken to avoid giving stress to the fish. The fish were not fed $24 \mathrm{~h}$ before and during the experimental period so that excretory substances may not influence the toxicity of test solutions. The mortality rate during acclimatization was less than $4 \%$.

\section{Determination of $L C_{50}$ :}

Four-day static renewal acute toxicity test (APHA et al., 1998) was used for the determination of $\mathrm{LC}_{50}$ values for mercury. Six replicates each containing ten fish (kept in glass aquarium containing $30 \mathrm{~L}$ of the test solution) were subjected to each concentration of the toxicant- mercuric chloride $(0.5,0.6,0.7,0.8,0.9,1.0$ and 1.1 $\mathrm{mg} / \mathrm{L}$ ) for the test. Mercuric chloride were firstly dissolved in distilled water and then the desired volume of the solution was mixed in tap water to obtain the above mentioned toxicant concentration. A control group with six replicates (each containing 10 fish) kept in 
$30 \mathrm{~L}$ tap water was also run. The solutions of all the aquaria (control and experimental) were renewed daily. Precautions were taken to remove the dead fish immediately because dead fish deplete dissolved oxygen which greatly affects toxicity data (Schreck and Brouha, 1975). Death in fish was confirmed when the movement of the operculum was stopped and the fish remain unresponsive when gently prodded at the caudal peduncle. The concentration of the toxicant and degradation products were not measured during the course of bioassay as the facilities for it were not available in the department.

The $\mathrm{LC}_{50}$ values at different exposure periods as well as their upper and lower confidence limits and slope functions were calculated by PoloPlus software version 2.0 Computer programme.

\section{Results and Discussion}

After exposure to various concentrations of mercuric chloride, the per cent mortality of H. fossilis at 24, 48, 72, and $96 \mathrm{~h}$ has been shown in Fig. 1 . The $\mathrm{LC}_{50}$ values of mercuric chloride for $H$. fossilis after 24, 48, 72 and $96 \mathrm{~h}$ are $0.96,0.91,0.81$ and $0.70 \mathrm{mg} / \mathrm{L}$, respectively (Table 1 ).

In the present study, the $\mathrm{LC}_{50}$ values of mercuric chloride for the fish Heteropneustes fossilis are $0.96 \mathrm{mg} / \mathrm{L}$ for $24 \mathrm{~h}, 0.91 \mathrm{mg} / \mathrm{L}$ for $48 \mathrm{~h}, 0.81 \mathrm{mg} / \mathrm{L}$ for $72 \mathrm{~h}$ and $0.70 \mathrm{mg} / \mathrm{L}$ for 96 h. Kumar and Gupta (2006) have reported 96 h $\mathrm{LC}_{50}$ value for mercury for fingerlings of Indian major carp at $270 \mathrm{mg} / \mathrm{L}$ water hardness and temperature $35 \mathrm{C}$ as 43.922 $\mu \mathrm{g} / \mathrm{L}$ for catla; $194.612 \mu \mathrm{g} / \mathrm{L}$ for rohu and $268.141 \mu \mathrm{g} / \mathrm{L}$ for mrigal, whereas at $16 \mathrm{C}$ temperature the $96 \mathrm{~h} \mathrm{LC}_{50}$ values were 52.755 $\mu \mathrm{g} / \mathrm{L}$ for catla; $228.15 \mu \mathrm{g} / \mathrm{L}$ for rohu and
$308.456 \mu \mathrm{g} / \mathrm{L}$ for mrigal. Similarly at water hardness of $560 \mathrm{mg} / \mathrm{L}$ and temperature $35 \mathrm{C}$ the $\mathrm{LC}_{50}$ values were $47.707 \mu \mathrm{g} / \mathrm{L}$ for catla; $222.069 \mu \mathrm{g} / \mathrm{L}$ for rohu and $281.449 \mu \mathrm{g} / \mathrm{L}$ for mrigal. Whereas at $16 \mathrm{C}$ temperature the $\mathrm{LC}_{50}$ values were $72.729 \mu \mathrm{g} / \mathrm{L}$ for catla; 278.347 $\mu \mathrm{g} / \mathrm{L}$ for rohu and $312.909 \mu \mathrm{g} / \mathrm{L}$ for mrigal. They have concluded that both water hardness and temperature played significant role in mercury toxicity. They have further stated that the test fishes were found most resistant with water hardness of $560 \mathrm{mg} / \mathrm{L}$ at $16^{\circ} \mathrm{C}$ and water hardness of $270 \mathrm{mg} / \mathrm{L}$ at both temperature- 35 and $16 \mathrm{C}$.

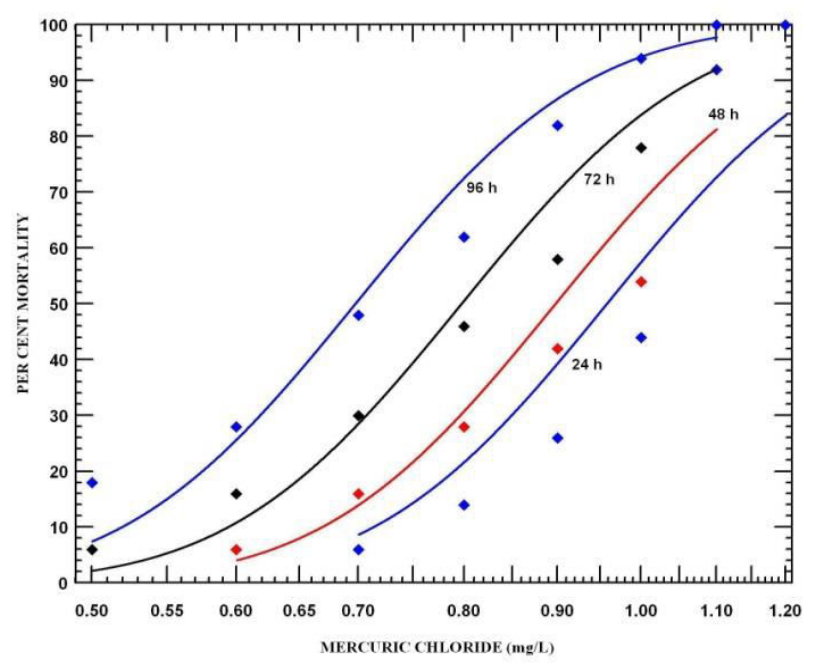

Fig. 1: Per cent mortality of the fish Heteropneustes fossilis after 24, 48, 72, and $96 \mathrm{~h}$ exposure to different concentrations of mercuric chloride.

Delvin (2006) have reported $96 \mathrm{~h} \mathrm{LC} 50$ value for methyl mercury (continuous flow condition) for fathead minnow embryo as 39 $\mu \mathrm{g} / \mathrm{L}$. Krishnani et al. (2003) have found $96 \mathrm{~h}$ $\mathrm{LC}_{50}$ value for mercury as $0.085 \mathrm{mg} / \mathrm{L}$ (for 11 $\pm 3 \mathrm{~mm}$ size) and $0.20 \mathrm{mg} / \mathrm{L}$ (for $24 \pm 4 \mathrm{~mm}$ ) for fry of Lates calcarifer. Alam and Maugham (1992) have recorded $96 \mathrm{~h} \mathrm{LC} 50$ value for mercury for common carp (Cyprinus carpio) as $0.16 \mathrm{ppm}$ (for smaller fish, size $3.5 \mathrm{~cm}$ ) and 
Table 1: $\mathrm{LC}_{50}$ value, slope function and confidence limits for mercuric chloride at different exposure periods for the fish $H$. fossilis

\begin{tabular}{|c|c|c|c|c|c|c|}
\hline \multirow{2}{*}{$\begin{array}{l}\text { Exposure } \\
\text { periods }\end{array}$} & \multirow{2}{*}{$\begin{array}{l}\text { Effective dose } \\
\quad(\mathrm{mg} / \mathrm{L})\end{array}$} & \multicolumn{2}{|c|}{ Limits(mg/L)* } & \multirow{2}{*}{$\begin{array}{c}\text { Slope } \\
\text { Function }\end{array}$} & \multirow{2}{*}{$\begin{array}{c}\text { ' } \mathrm{t} \text { ' } \\
\text { ratio }\end{array}$} & \multirow{2}{*}{$\begin{array}{l}\text { Hetero- } \\
\text { geneity }\end{array}$} \\
\hline & & LCL & UCL & & & \\
\hline $24 \mathrm{~h}$ & $\begin{array}{l}\mathrm{LC}_{10}=0.803 \\
\mathrm{LC} C_{50}=0.969 \\
\mathrm{LC} C_{90}=1.134\end{array}$ & $\begin{array}{l}0.598 \\
0.896 \\
1.056\end{array}$ & $\begin{array}{l}0.880 \\
1.043 \\
1.345\end{array}$ & $\begin{array}{c}13.268 \\
\pm \\
1.410\end{array}$ & 9.411 & 3.236 \\
\hline $48 \mathrm{~h}$ & $\begin{array}{l}\mathrm{LC}_{10}=0.678 \\
\mathrm{LC}_{50}=0.911 \\
\mathrm{LC}_{90}=1.144\end{array}$ & $\begin{array}{l}0.292 \\
0.812 \\
1.023\end{array}$ & $\begin{array}{l}0.786 \\
1.037 \\
1.595\end{array}$ & $\begin{array}{c}9.441 \\
\pm \\
1.072\end{array}$ & 8.806 & 3.979 \\
\hline $72 \mathrm{~h}$ & $\begin{array}{l}\mathrm{LC}_{10}=0.559 \\
\mathrm{LC}_{50}=0.818 \\
\mathrm{LC}_{90}=1.076\end{array}$ & $\begin{array}{l}0.425 \\
0.765 \\
0.998\end{array}$ & $\begin{array}{l}0.635 \\
0.872 \\
1.215\end{array}$ & $\begin{array}{c}8.504 \\
\pm \\
0.866\end{array}$ & 9.817 & 1.498 \\
\hline $96 \mathrm{~h}$ & $\begin{array}{l}\mathrm{LC}_{10}=0.454 \\
\mathrm{LC}_{50}=0.709 \\
\mathrm{LC}_{90}=0.964\end{array}$ & $\begin{array}{l}0.373 \\
0.675 \\
0.915\end{array}$ & $\begin{array}{l}0.510 \\
0.741 \\
1.033\end{array}$ & $\begin{array}{c}8.618 \\
\pm \\
0.904\end{array}$ & 9.533 & 0.729 \\
\hline
\end{tabular}

$0.77 \mathrm{ppm}$ (for longer fish, size $6.5 \mathrm{~cm}$ ). For Notopterus notopterus the $96 \mathrm{~h} \mathrm{LC}_{50}$ value has been reported as $0.44 \mathrm{mg} / \mathrm{L}$ (Verma et al., 1983). The $96 \mathrm{~h} \mathrm{LC}_{50}$ value for several fish species has been given by Boening (2000) which ranged from 24 to $2000 \mu \mathrm{g} / \mathrm{L}$.

Guedenon et al. (2012) have reported the toxicity of mercury $\left(\mathrm{HgCl}_{2}\right)$ to African catfish, Clarias gariepinus. They determined the $96 \mathrm{~h}$ $\mathrm{LC}_{50}$ value of mercury which is $0.60 \mathrm{mg} / \mathrm{L}$ for the fish Clarias gariepinus. Zakaria et al. (2016) reported $\mathrm{LC}_{50}$ values for 24,48 and 96 $\mathrm{h}$ for Poecilia reticulata as 342.3, 179.2 and $95.8 \mu \mathrm{g} / \mathrm{L}$ and for Rasbora sumatrana as 156.7, 134.4 and $93.8 \mu \mathrm{g} / \mathrm{L}$, respectively. $\mathrm{LC}_{50}$ values of mercury in Oreochromis mossambicus were $0.73,0.69,0.63$ and 0.58 ppm for 24, 48, 72 and $96 \mathrm{~h}$, respectively (Vasanthi et al., 2019).

\section{Conclusion}

It is concluded that $H$. fossilis is hardy fish when compared to other fish species regarding the toxicity of mercury. Toxicity of mercury to different fish species is difficult to compare as they are influenced by various factors such as temperature and environmental conditions.

\section{References}

Alam MK and Maughan OE. (1992) The effect of melathion, diazinon and various concentrations of zinc, copper, nickel, lead, iron and mercury on fish. Biological Trace Element Res. 34: 225-236.

APHA, AWWA and WPCF. (1998) Standard methods for the examination of water and wastewater. $15^{\text {th }}$ edition, APHA, Washington, DC.

Arabi M. (2004) Analyses of impact of metal ion contamination on carp (Cyprinus carpio L.) gill cell suspensions. Biological Trace Element Res. 100: 229-245. 
Boening DW. (2000) Ecological effects, transport, and fate of mercury: a general review. Chemosphere 40: 1335-1351.

Crump HL and Trudeau VL. (2009) Mercury induced reproductive impairment in fish. Environ. Toxicol. Chem. 28: 895-907.

Drevnick PE and Sandheinrich MB. (2003) Effects of dietary methylmercury on reproductive endocrinology of fathead minnows. Environ. Sci. Technol. 37: 4390- 5006.

Delvin EW. (2006) Acute toxicity, uptake and histopathology of aqueous methyl mercury to fathead minnow embryos. Ecotoxicol. 15: 97-110.

Guedenon P, Edorh AP, Hounkpatin ASY, Alimba CG, Ogunkanmi A, Nwokejiegbe EG and Boko M. (2012). Acute toxicity of mercury $\left(\mathrm{HgCl}_{2}\right)$ to African catfish, Clarias gariepinus. Res. J. Chem. Sci. 2: 41-45.

Gupta N. (2014) Architectural changes in kidney and liver of Channa punctatus when exposed to mercury. J. Emerging Technol. Innovative Res. 1: 463-471.

Joshi D, Mittal D, Shrivastav S, Shukla S and Srivastav Ajai K. (2011) Combined effect of N-acetyl cysteine, zinc and selenium against chronic dimethylmercury induced oxidative stress: A biochemical and histopathological approach. Arch. Environ. Contam. Toxicol. 61: 558-567.

Joshi D, Mittal D, Shukla S and Srivastav Ajai K. (2012) Therapeutic potential of $\mathrm{N}$-acetyl cysteine with antioxidants (Zn and Se) supplementation against dimethyl mercury toxicity in male albino rats. Experim. Toxicol. Pathol. 64: 103-108.

Josh, D, Mittal D, Shrivastav S, Shukla S, Srivastav Ajai K and Srivastav SK. (2013) Protective effect of combined therapy with dithiothreitol, zinc and selenium protects acute mercury induced oxidative injury in rats. J. Trace Elements Med. Biol. 27: 249-256.
Krishnani KK, Azad IS, Kailasam M, Thirunavukkarasu AR, Gupta BP, Joseph KO, Muralidhar $M$ and Abraham M. (2003) Acute toxicity of some heavy metals to Lates calcalifer fry with a note on its histopathological manifestations. J. Environm. Sci. Hlth. 38: 645-655.

Kumar A and Gupta AK. (2006) Acute toxicity of mercury to the fingerlings of Indian major carps (Catla, rohu and mrigal) in relation to water hardness and temperature. J. Environ. Biol. 27: 89-92.

Sarmento A, Guilhermino L and Afonso A. (2004) Mercury chloride effects on the function and cellular integrity of sea bass (Dicentrarchus labrax) head kidney macrophages. Fish Shellfish Immunology 17: 489-498.

Schreck CB and Brouha P. (1975) Dissolved oxygen depletion in static bioassay system. Bull. Environ. Contam. Toxicol. 14: 149-152.

Shah SL and Altindag A. (2004) Hematological parameters of tench (Tinca tinca L.) after acute and chronic exposure to lethal and sublethal mercury treatments. Bull. Environ. Contam. Toxicol. 73: 911- 918.

Vasanthi N, Muthukumaravel $\mathrm{K}$, Sathick $\mathrm{O}$ and Sugumaran J. (2019) Toxic effect of mercury on the freshwater fish Oreochromis mossambicus. Res. J. Life Sci. Bioinform. Pharmaceut. Chem. Sci. 5: 364-376.

Verma SR, Jain M and Tonk IP. (1983) In vivo effect of mercuric chloride on tissue ATPases of Notopterus notopterus. Toxicol. Letters 16: 305-309.

Zakaria NA, Ahmad AK and Mahazar MA. (2016) Acute toxicity of mercury to three freshwater organisms species in Malaysia. Australian J. Basic Applied Sci. 10: 124-129. 